\title{
Migration in the Albania of the post-1990s: triggered by post-communist transformations and facilitator of socio-demographic changes
}

\section{Introduction}

Albania, one of the poorest countries in Europe, has experienced one of the greatest migration flows of the last two decades. (Carletto et al, 2004)

Migration in Albania has been a dominating process of everyday life, shaping the social and economic situation of the country and of the population. (UNDP, 2000)

Migration is perhaps the most important political, social and economic phenomenon in postcommunist Albania. (INSTAT, 2004)

Migration - the phenomenon that is at the heart of economic, social and cultural change in Albania over the past 15 years. (King, 2005)

Statements that make us think - why is this phenomenon of such importance in Albznia?

'The last piece of domino,' as communist Albania was called in the western media, fell one year after the Berlin Wall, in December 1990 (Lami, 1999). In the context of former communist countries in eastern Europe, it took more time and effort for Albania to pass through what is generally accepted as one of the most repressive and centralised communist regimes in the world. Over the last seventeen years, Albania has experienced remarkable political, social and economic developments in the transition from a closed and centralised economy towards one based on an open market.

The transformation process, developed during a period of economic and political unrest, has affected social and demographic changes and was accompanied by large flows of people moving within and out of the country. Migration, both internal and international, has increasingly been seen as a process involving economic developments, political changes, urbanisation, modernisation and demographic changes. According to Mullan (2001), migration has dramatic social, cultural and economic consequences for individuals, families, communities, society, regions and the country as a whole. As such, migration (internal and external) has been one of the most dynamic features of the Albanian transition. The role of migration is reflected in the total population decrease; the massive urbanisation of some areas and the depopulation of others; increased levels of conflict in urban areas because of the difficult integration process of migrants; social and cultural transformation in the regions; changes in the sex and age structure of the population; and other dynamic changes.

Different data suggest that around 1000000 Albanians have moved temporarily or permanently over the border since the beginning of the transition period (INSTAT, 2004; Barjaba, 2003; Labour Market Review of Albania, 2006). Moreover, in the last census (2001) the urban population increased visibly compared with the previous one, 
from 33.5 per cent in 1979 to 35.7 per cent in 1989 and then to 42.1 per cent in 2001, due to internal migration (INSTAT, 2002). According to LSMS (2005), the urban population has continued to grow in the subsequent years. Internal migration flows are largely directed from the rural northern and southern regions towards the urban areas in the central region and the lowlands. The population of the capital (Tiranë) alone is estimated to have grown from 200000 in the early 1990s to approximately 800000 in 2006.

The topic of this article is a discussion and a description of the migration process as driven by the post-communist transformations and as a facilitator in the socio-economic and demographic developments that there have been in Albania following the 1990s. The main goal is to provide more insights into the central role of migration in transformation processes. Firstly, we try to understand the role of the economic and political transformation on the levels, patterns and directions of migration. Secondly, we try to analyse the role of migration on further social and demographic transformations. As such, we raise two main questions: 'how did the transformation processes in Albania in the post-1990s affect the levels and patterns of migration over time?'; and 'what is the role of migration in the social and demographic changes that have followed the transformation processes?'

The article starts with a brief discussion of the main political and economic changes in the country in the context of the transformation that followed the demise of the communist regime. It then continues with a presentation of the dynamics of internal and international migration in Albania, focusing on the importance of this phenomenon as a promoter of socio-demographic changes. This is followed by an intention to develop a chronology of migration as triggered by the main economic and political changes during the transition period. Finally, the article closes by identifying some insights into the need for effective migration polices and further research on issues concerning migration, especially in the Albanian transformation context.

\section{The context of the transformation}

Lami (1999) notes that, following the demise of the communist regime:

Albanians have thrown down the walls but have not built the bridges and, as it is known in the Balkans, it is more difficult to construct than to demolish.

This statement suggests that it would not be an easy task for Albania to go through this difficult transformation period. The transition from a socialist society towards a democratic one is a process that implies different transformations and cannot be seen as a single process (Kok, 1999). Indeed, chains of transformations take place together: the political transformation from communism to democracy; economic transformations from centralisation to the open market; and many other social and cultural changes.

Following the demise of communism, the political system and the economy are likely to experience the main dynamic transformations. Furthermore, these transformations are expected to have a strong impact on social and demographic changes. 


\section{Political transformation}

The end of the 1980s signalled the end of the communist regime all over the eastern central bloc. However, eastern central Europe is not a homogenous region. At the time the transformation took hold, at the beginning of the $1990 \mathrm{~s}$, countries in the region had different starting positions (Kok, 1999). Owing to the late demise of the communist regime, Albania started the transition process long after other centrally planned economies (Sadiraj, 1999): Albania has, as a matter of fact, undergone a more problematic and difficult transition period compared to other former communist countries. This situation is a consequence of the isolation and self-reliance policies applied by the communist regime in the country. The political, economic and social reforms that the communist regime implemented pushed the country towards total isolation not only from developed western countries but also from the communist bloc. ${ }^{1}$ For nearly five decades, Albania experienced total centralisation without any liberalising reforms as a unique case among all former communist countries. By the end of the 1980s, economic and political conditions had further deteriorated until total collapse in 1990, when an urgent need for radical political and economic changes inevitably came along.

Following 1990, a period of democratic transformations that was typical all over eastern central Europe also began in Albania. All these transformations happened together to introduce plural democracy and the market economy instead of the centrally-planned economy.

\section{Economic transformation}

The last decade of the $20^{\text {th }}$ century witnessed one of the largest economic experiments as former communist countries embarked on attempts to transform their economies from a centrally-planned to a market-based system (Castaldo et al, 2005).

Following 1990, Albania, together with other eastern central European countries, has undergone significant political and economic transformation towards a democratic society with an open market, private ownership and free competition. Important reforms have been implemented, such as price and trade liberalisation; the privatisation of state-owned enterprises in strategic sectors; and the development of the private sector. However, these economic reforms did not follow the line of gradual transformation and development. The transformations started mainly at 'zero' level, ${ }^{2}$ which made it very difficult for Albania to adapt to the new rules of the open-market economy. ${ }^{3}$

Nevertheless, following the first chaotic years, the economy of the country started to stabilise and to show trends towards growth. According to the International Monetary Fund (2006), Albania, after undertaking many structural reforms, was distinct as one of the fastest growing of the transition economies. Consequently, for the 19982004 period, average annual real GDP grew by 7.5 per cent (IMF, 2006). Moreover,

1 Albania broke first with Yugoslavia in 1948; then with the Soviet Union in 1961; and, in the end, with China in 1977, becoming a unique case of self-isolation.

2 According to Doka (2005) after the changes following the 90s, economic developments tend to start from a 'zero' level, meaning that everything was destroyed out of the previous communist developments.

3 More specifically, the main economic developments are presented below. 
the World Bank (2006) $)^{4}$ reports that poverty rates in Albania have reduced more dramatically than in any other country of the western Balkans in the past several years. Following these economic trends, there is the hope that Albania would start to 'build' the difficult road to Europe.

Progress achieved in the political and economic agenda during transition did not cover the country homogenously: significant regional disparities may be observed. For instance, the disaggregated result of the Human Development Index (2002) in Albania shows substantial socio-economic development differences between the various regions of the country, as well as between various districts within the same region. Poverty is found to be higher in rural areas and is disproportionately concentrated in the remote north-eastern part of Albania 5 (INSTAT and World Bank, 2003).

After 1990, these disproportionate developments had an impact on most of the social and demographic changes in the country. One of the main areas where socio-economic development disparities have had a strong impact is migration and urbanisation.

\section{Socio-demographic transformation}

For demographers, it is a well-known phenomenon that political and economic changes affect the social and demographic behaviour of the population (Kupiszewski et al, 1994). At the beginning of the 1990s, Albania started the parallel economic and political transformations towards democracy. Consequently, it was expected that the combination of these transformations would bring dynamic changes also as regards the social and demographic developments shaping the behaviour of individuals.

According to Sjöberg and Tammaru (1999), migration is one of the many areas where the demise of central planning and one-party rule in the former communist countries is expected to make a difference.

The dismantling of the Iron Curtain was widely anticipated to be a precursor of mass migration, given that migration had been denied for so long and reflecting the obvious economic divide between East and West. (Layard et al, 1992)

\section{Massive migration as a facilitator of demographic transformation of Albanian society after the $90 \mathrm{~s}$}

Cole and Filatotchev (1992) argue that, leaving behind central planning, migration patterns of a different character and extent are likely to result as these economies move towards the open market. Furthermore, Sjöberg and Tammaru (1999) have noted that economic restructuring, changes in the housing market and the abolition of the administrative controls of the previous regime are likely to produce a rather different set of opportunities and constraints confronting the prospective migrant.

The mass migration anticipated in some early studies on the transition process did not follow the same trends and levels everywhere in post-communist countries. Ac-

4 Western Balkans Programmatic Poverty Assessment Progressive Review 2001-2005, cited by Albania Urban Sector Policy Analyses.

5 According to INSTAT and the World Bank (2003), in the north-east of Albania are concentrated 21 per cent of all the poor while only 12 per cent of the population live in the region. 
cording to Castaldo (2005), most of the countries in eastern central Europe experienced generally modest population mobility compared to the original expectations. From the data available, Albania proved to be a kind of exception in the former communist bloc, experiencing one of the greatest migration flows in the two last decades in Europe (Carletto et al, 2004). In the summer of 1990, a decree was issued giving freedom of movement and official recognition of the private sector (Aliaj et al, 2003). Quoting Aliaj et al (2003):

This act symbolically may be compared to opening the dyke of a huge lake without having made plans or taken any measures to channel the deluge of water accumulated in the lake in the right direction to avoid mass flooding.

The most relevant background context for the mass migration of Albanians is embedded in the outgoing transformations from a socialist society towards a democratic one, together with the difficult economic conditions and unstable political situation that followed.

Moreover, the astonishing migration levels can be seen as a response of the population to the strict isolation and strong administrative control on migration during the communist regime. Following the 1990s, the massive migration constitutes one of the most important factors that have affected and facilitated the social and demographic developments in the country.

Some theoretical insights: the migration decision process, macro and micro influences

The main purpose of giving some theoretical insights is to provide a basis for understanding the astonishing migration levels triggered by the transformation and its central role as a facilitator for demographic and social changes.

\section{Neo-classical migration theory - push and pull factors}

According to the neo-classical approach, migration is self-correcting because it alters demand for and supply of labour at origin and at destination. The key driver variables of the neo-classical approach are the wage and unemployment levels. As such, the decision to migrate and the process of migration are triggered by a set of push and pull factors. According to Lee (1966), the push and pull factors are associated with the area of origin, the area of destination, intervening obstacles and personal factors. The potential migrant perceives differently, according to his or her demographic characteristics and economic conditions, the set of pull factors and push factors at both origin and destination. Furthermore, between origin and destination there are a set of intervening obstacles which may facilitate or retard the decision to migrate.

On the one side, the dynamic transformations during the transition period, the difficult economic and political situation in the country in general, and in some regions in particular, together with the social and demographic characteristics of the population (young age groups, high unemployment rates), have constituted the push factors for the prospective migrants.

According to INSTAT $(1998,2001,2002)$, unemployment rates in Albania have been decreasing in recent years compared with the first years of transition, from over 25 per cent in 1993 to 14.4 per cent in 2004. Nevertheless, these rates are much higher 
than the levels in EU countries. The situation is even worse in some districts, such as Has, Kurbin and Pukë, where the unemployment rate reaches more than 40 per cent (HDPC, 2002). In fact, these districts have lost a great percentage of their population due to migration. As such, high unemployment rates constitute one of the main push factors of internal and external migration in Albania.

On the other side, the better economic development of some regions, with greater employment opportunities and higher wages, constitutes the pull factors. As such, within the country, Tiranë offers a greater range of opportunities in terms of the labour market and higher wages, being the most attractive region for internal migrants.

Moreover, international migration is also triggered by better wages and better living conditions and opportunities in western countries.

These push and pull factors have shaped the migration patterns that we have observed since the 1990s. Furthermore, migration, with its patterns and directions, has affected the demographic and social evolution of the regions in particular and of the country in general.

\section{Structural individualistic approach and behavioural model of the migration process}

On the one side, the structural individualistic approach proposed by Coleman (1990) explains processes at the macro level (society) analysing individual actions. Based on this theory, a micro-macro model can explain the migration decision and directions. Migrants, depending on the evaluation of the new opportunities that come along with the transformation period, can decide whether to migrate.

On the other, Gardner (1981) introduced a model that presents the macro level influences on the migration decision process. In the behavioural model of the migration process is included the concept of stress, which is seen as originating in the needs and expectations of the household on the one hand and the environment on the other (Boyle et al, 1998). This model, together with the structural individualistic approach, sets a more complete theoretical explanation of the migration decision process and its patterns.

In Albania, after the 90s, the changes in the labour and housing markets, as well as changes in the structure of the economy and other social developments, are expected to affect individuals' decisions to migrate while shaping at the same the patterns and directions of migration. The individual decision to migrate is taken after the potential migrant evaluates the new opportunities that come along with the transformation processes.

Moreover, an important role in the decision to migrate and the destination choice is played by the demographic and social characteristics of individuals. As such, in the international migration are mainly involved those of working age and the male population, while those migrating within the country are mainly female and younger age groups.

\section{New economics of migration}

In the social network literature, the nuclear family perspective is confronted with the collective extended family perspective. The former treats migration as a selective process. Those who migrate are the ones who are non-conformist and who are critical 
of the status quo in their area of origin. Social capital is rooted in 'place' and migration destroys social capital.

According to the collective approach, migration involves the construction of dispersed livelihood systems that reduce vulnerability. Migration creates new forms of social capital, both in the destination area and across a space (multi-spatial).

In the Albanian context, family and kinship networks and connections are very important factors that determine the decision to migrate and the destination choice of migrants. Moreover, these connections create what is known in the literature as 'chain migration', as well as social networks at the destination. In the Albanian context, we find a strong and dependent relationship between internal and international migration. As such, given strong family ties in Albania, international migration finances, via remittances, the internal migration of other family members as a second stage. The family will be further reunited in case of return migration or in case of further international migration.

In short, family and social networks create chain migration, within the country or abroad, while shaping the directions and patterns of migration.

\section{Effects of migration on socio-demographic changes}

Internal and international migration, firstly from a demographic point of view, accounts in absolute terms for the numerical increase or decrease in the total population and, secondly, shows the degree of change in the territorial distribution of the population during a certain period (INSTAT, 2001). Given the magnitude of migration flows in Albania, we can see this process both as a necessity for the socio-economic evolution of the regions and of the country in general and as a facilitator of socio-demographic changes such as urbanisation, socio-cultural transformation, age and sex structure, educational level and other developments.

After the 1990s, apart from the economic and political reforms, many other social and demographic reforms have been undertaken. The stringent control of, and restrictive policies against, urbanisation and freedom of movement for people during several decades under the communist regime were finally abolished and people, depending on their opportunities and interest, could freely choose their place of residence within the country or abroad. During this period, migration has been a spontaneous phenomenon; there have not been any migration policies to orient and control the levels and directions of migration. In these conditions, migration has played a central role in shaping the social and demographic development of the regions and of the country as a whole. In the section that follows, we discuss the effects of the migration process.

\section{Effects of international migration}

The massive emigration of Albanians after the 1990s has had positive and negative consequences as regards the socio-economic and demographic development of the population in Albania.

\section{a. Positive consequences}

1. One of the most positive effects of emigration is the income generated by remittances, in the form of financial and material goods, that emigrants send back home. Remittances from emigrants play an impressive role in economic performance as well as in the improvement of life for a good part of the popu- 
lation. According to INSTAT (2004), remittances currently account for 13 per cent of GDP.

2. Besides the financial benefits, many emigrants have gained professional and intellectual skills through the professions they perform abroad and the training they may have received. According to Doka (2005), the skills and training that have been gained are, in the case of return migration, used and applied in different sectors of the economy.

3. Emigration also has a positive effect on the labour market. A high percentage of emigrants are part of the working age group (Bërxholi et al, 2005). The emigration of this age group has played an important role in decreasing unemployment rates in Albania. Moreover, remittances have created new labour market opportunities for the population. The revenue from emigration is often used to establish small and medium enterprises and businesses, employing more people and decreasing unemployment rates yet further. Emigrants as such constitute a major potential source of labour for the growing Albanian economy. ${ }^{6}$

\section{b. Negative consequences}

1. According to INSTAT (2004), in the period from 1989 to 2001 the total population of Albania decreased by 6.5 per cent. According to different estimations, around 1000000 people emigrated during this period, recognising the phenomenon as the main factor affecting the total population decrease.

Population censuses since 1945 have captured the evolution of demographic changes at different moments in time. During the communist regime, as a result of pro-natalist attitudes, the prohibition of emigration and other population-related policies, the population was continuously growing: from $1.1 \mathrm{mil}-$ lion at the 1945 census to 1.4 million in 1959; 2 million in 1969; 2.6 million in 1979 and 3.2 million in 1989. ${ }^{7}$ In other words, in absolute terms the total population of Albania increased from 1 million in 1945 to more than 3 million in 1989. Following the democratisation processes after the $90 \mathrm{~s}$, the last census (2001) showed a general decrease in the total population. A comparison of the last two censuses $(1989,2001)$ shows that the population has decreased from 3.2 million to 3 million, or by 6.3 per cent.

2. Besides the absolute decrease in the population, the last census shows a marked loss of population in the north-east part of the country and in some areas in the remote south. The loss of population in these regions can be attributed to international migration as well as to internal migration towards more attractive and developed regions. As such, the population loss in southern parts

6 To quote the Labour Market Review for Albania: 'There is some evidence that returning migrants are already making a valuable contribution: around a third of the owner-operators of small businesses in Tirana interviewed in a recent study had work experience from abroad, and some 68 per cent of these considered their foreign experience to be very useful for their business.'

7 Collected data from different Statistical Yearbooks from 1950, 1958, 1966, 1970, 1989, 1999 and 2001, and censuses found in the general archives of the state. 
of Albania is attributed mainly to international migration to Greece. The population loss in the north-eastern part is attributed mainly to internal migration to the central region. However, in recent years, there has been an increase in internal migrants from southern regions as well as an increase in international migrants from northern parts.

3. One of the main negative effects of emigration is what is known in the literature as the 'brain and skill drain'. Many intellectuals have left the country because of the difficult economic and political conditions and in search of better opportunities in western European countries or even further afield in the USA and Canada. Based on a report on the 'brain drain' from central and eastern Europe, 38.5 per cent of Albanian intellectuals have emigrated while the average for other eastern European countries is 8.6 per cent. According to Gedeshi et al. (1999), more than 45 per cent of the researchers and intellectuals from the universities and research institutes of the country have emigrated.

4. Moreover, emigration is an age- and sex-selective process involving the most vital parts of the population. Misja (1998) points out that the structure of emigrants is very young; more than 50 per cent are in the 20-29 age group, while Doka (2005) estimates that 70 per cent of emigrants are male.

5. Emigration has an individual character. The first to move is usually the head of the family (later on, perhaps followed by a family reunion). This form of emigration has generated many other social problems in the family, household, community and society. As such, there has been an observed increase in divorce rates while the marriage rate has decreased (Bërxholi and Doka, 1995).

\section{Effects of internal migration}

During the communist regime, the directions and levels of migration were very controlled and oriented by the state. The removal of barriers to the free movement of people in Albania in the early 1990s was accompanied by a huge wave of migration. Following the 90s, migration has been characterised by an absence of migration policies. Consequently, there has been a redistribution of the population among the regions, following spontaneous trends and directions. Nevertheless, the main direction of internal migration that has taken place in Albania since 1989 has been from rural to urban areas and from northern to central regions. The main consequences of internal migration are presented below.

1. One of the main effects of internal migration is de-populating some areas while over-populating other regions. According to several sources and data sets (INSTAT 2002, 2003, 2004; LSMS, 2002, 2003, 2005), the most serious population loss is observed in the rural north, as well as in the rural south, particularly villages in high up mountainous areas. The regions that have gained the most in terms of total population are lowland areas interior to the coast, such as Tiranë, Durrës, Elbasan, etc. Between 1998 and 2002, the rural population fell by 15 per cent (INSTAT, 2004) while urban areas, especially Tiranë, grew disproportionately. This figure is in contrast to the previous census in 1989, which showed that the rural population actually increased by 20 per cent (INSTAT 2004). These levels of urbanisation are the result of rural-urban migration, given that fertility rates are much higher in rural areas compared with urban ones (Bërxholi, 2005). The massive migration towards urban areas has promoted chaotic and disproportionate 
development in these areas (UNDP, 2000). The urban population has continued its increase in recent years and, according to different estimates, more people live in urban areas than in rural regions.

2. An inevitable consequence of internal migration is that a socio-cultural transformation has begun in Albania. Different cultural traditions that were locally rooted are now being carried to different areas of the country where they are placed in dynamic confrontation (UNDP, 2000). The original identity of urban areas has often changed considerably due to the different socio-cultural norms and values of migrants to those of urban residents. Fuga et al. (1998) points out that urban areas continue to be confronted with a massive turnover in their population. Consequently, according to UNDP (2000), it seems difficult for urban residents to accept new comers while, on the other side, migrants may feel like they are strangers and excluded. This situation often provokes discrimination and aggression between residents and migrants.

3. Internal migration involves the most educated and skilled part of the population in the uplands of the north and south of the country. Those leaving are the active age groups and the higher educated. The 2001 census counted 46 per cent of individuals with an upper-secondary or higher education qualification in towns and cities, compared with only 16 per cent in rural areas. In 1989, this category had accounted for 22 per cent in rural areas and 50 per cent in urban areas. Between these two censuses, rural areas lost 41 per cent of their highly qualified individuals while urban areas increased these numbers by 9 per cent (INSTAT, 2001). The higher educated and skilled migrants move towards developed urban areas with a greater range of opportunities. As such, migration facilitates a better distribution of human capital according to economic opportunities and conditions.

4. Another important impact of internal migration is in the abandonment of arable land and rural communities, accompanied by economic and environmental problems such as the degradation of the land and of agriculture (Bërxholi et al, 2005). The abandonment of these regions also has social effects. King (2004), given Albanian family ties and the cultural context, points out that this abandonment is very painful for the older generation. He argues, moreover, that remittances constitute only a partial compensation for what he calls cross-generational family break up since family reunion or return migration becomes less likely as time passes.

\section{Migration chronology as shaped by post-communist developments}

Albania embarked on a route towards a democratic and open society from a repressive isolation during communism under the policy of self-reliance that was applied before the 1990s. Some limited economic and political reforms aimed at liberalisation had started by the end of the 1980s. ${ }^{8}$ These reforms were partial and not radical or coherent which resulted, at the beginning of the 1990s, in the breakdown of the communist regime and economic crises. A tense political situation emerged, with a growing discontent amongst the population as well as revolt.

8 According to Banja (1990), during 1985-1990 we could see some attempts to decentralise decision-making. These macroeconomic reforms aimed at decentralising and liberalising the market. 
The years that would follow have been difficult with their vicissitudes, making the transition period a challenge for Albania. The transition was hindered by the demonstrations against, and the opposition of the population to, the communist regime in 1990-1991; the liberalisation reforms in 1993-1996; the crises in the pyramid schemes in 1997; the Kosova crisis in 1999; and the frequent conflicts between the political powers. For these very specificities of Albania, this transition period would leave very distinctive effects on social, economic, demographic and urban development all over the country. As such, the migration process, in its dimensions, intensity, direction and motives, has been determined by these transformations that occurred in Albania in this period (INSTAT, 2004).

In this section, we will present a migration chronology as it has been shaped by economic and political transformation through the transition period. The scheme of migration chronology draws widely on the available literature concerning Albanian migration and is strongly confirmed by the existing data (Pastore, 1999; King, 2005; King and Vullnetari, 2003; Vullnetari 2007; INSTAT 2001; UNDP, 2000; Barjaba, 2003; etc). In addition, we want to give further insights in understanding the role of economic and political transformations during the transition period in shaping the migration chronology.

1990: the demise of the communist regime - open borders (administrative and national) after 45 years of extreme isolation

At the beginning of the 1990s, Albania was experiencing the transition from a communist regime and a difficult start towards an open market economy. Economic indicators and political events were changing dynamically and, for the first time in almost five decades, Albanians were free to move.

The collapse of communism resulted, additional to other reasons, from people's high levels of dissatisfaction with the regime. For 45 years, the population had been obliged to live in total isolation, under political pressure and extremely difficult economic conditions. In this tense situation following the liberalisation of passports in June 1990, the first political exodus known as the 'embassy phenomenon' took place. This political exodus gave the first real shock to communism. More than 5000 people crossed the walls of the western embassies searching for better living conditions and as a response to the communist regime. Later on, these people were allowed to enter their countries of choice, mainly Germany, France and Italy. According to Vullnetari (2007), it was this first wave of emigration which created the basis for chain migration in western Europe.

Without any doubt, this phenomenon was the witness of communism's demise and it is generally seen as a response of people to the isolation and denial of foreign travel, as well as a result of the difficult economic conditions. This first wave of emigration signalled the starting point of numerous and continuous flows of people, mainly to Italy and Greece as the nearest countries to reach.

Data for this period, because of the difficulties in record-keeping, are not accurate; we have only a few estimates of the levels of international migration. As such, it is estimated that approximately 20000 Albanians left the country in 1990. 


\section{1: first democratic election - mass migration to Italy and Greece}

At the beginning of 1991, the general political and economic situation was turning into a real crisis. Finally, in March 1991 the first democratic and pluralist election was held. Muco (1997) points out the importance of this moment as the first phase of economic reforms. Moreover, he argues that these reforms were accompanied by controversies, political instability and confusion.

The victory of the former Party of Labour in the first democratic elections was followed by massive opposition spread all over the country, resulting in widespread strikes, especially in Tiranë. In this condition, the economy was collapsing and the political situation was very tense. The general macroeconomic achievements until that moment were deteriorating. According to the IMF economic review for Albania (1994), output decreased by 50 per cent in 1992 compared with the end of 1990, while the external debt reached 30 per cent of GDP. Inflation was also increasing sharply, at 15 per cent monthly by the beginning of 1992 (IMF, 1994). Moreover, unemployment rates, criminality and insecurity were continuously rising.

The emerging situation created the push factors for a second extraordinary wave of emigration. In March 1991, more than 25000 people were engaged in migration to southern Italy. People were trying to reach Italy and Greece by any means, risking their lives crossing thousands of miles over the sea in inappropriate, yet packed, boats or by crossing dangerous paths of a thousand miles on foot. In just one month, over May-June 1991, more than 100000 people would cross the Albanian border, with 76 per cent headed for Greece and 24 per cent for Italy (Bërxholi and Doka, 1996).

The first waves of emigrants were, under the status of refugees, generally accepted by foreign destination countries but, after the democratic election and the general economic political changes, a process of repatriation started; and Albanian migrants were no longer accepted as refugees. This situation reinforced illegal migration, especially to Greece and Italy, making its documentation very difficult. Nonetheless, there is an estimate that 300000 people emigrated from Albania between 1991 and 1992 (Bërxholi and Doka, 1997; Carletto et al, 2006). According to different sources of data, ${ }^{9}$ during 1991-1992 alone around 20000 people emigrated every month resulting, by the end of 1992, in a 9 per cent decrease in the total population compared with 1989.

Moreover, the parliamentary election lists of 1991 and 1992 show evidence related to the massive emigration of the population. According to these lists, many districts, as well as the country as a whole, observed a considerable loss of population in this period. Internal migration was not, during this period, yet a concern and the loss of population in many districts of the country was thus the result of massive emigration. This statement is supported also by the observed decrease in the total population of the country. According to the parliamentary and local lists for the March $1991 \mathrm{elec}-$ tion, the total population of Albania had decreased by 2.99 per cent since 1989 while in July 1992, this rose as high as 5.58 per cent.

The south-eastern regions of Albania have experienced the major loss in the population, due to the close vicinity with Greece, while the north shows a moderate de-

9 INSTAT, 2001; Doka, 2005; Misja, 1998; etc. 
crease in population as a result of internal migration mainly to Tiranë, Durrës, Lezhë, etc.

Internal migration during this period has compensated to a certain extent the loss of population in some regions as a result of emigration. However, internal movements have been characterised by a lack of organisation and direction policies. As such, internal migration was accompanied by a massive, chaotic and disproportionate development of urban zones and the abandonment of rural areas. This tendency would be reinforced in the future.

1993-1996: economic growth and political stability - steady emigration rates and rising internal migration

Following the chaos and difficulties of the first years, by the end of 1992 the government had implemented serious economic reforms. The former Party of Labour resigned under the pressure of widespread strikes and opposition. Even the coalition government which came to power after the resignation of the former Party of Labour did not succeed with the macroeconomic reforms undertaken. After the Democratic Party withdrew from the coalition government, new elections were held on $22 \mathrm{March}$ 1992.

The Democratic Party won the elections and immediately launched very ambitious economic and social reforms. The programme implemented by the new government was financially supported by the World Bank, the IMF and the European Community (IMF, 1994). Moreover, Albania received financial aid also from other countries, such as Italy, Greece, Germany and the United States. As a result, the country embarked on a period of high and steady economic growth. Inflation decreased from 237 per cent in 1992 to 31 per cent by the end of 1993, to 16 per cent in 1994 and only 5 per cent in 1995 (IMF, 1994, 1996; INSTAT, 1998; Muco, 1997; etc).

An important role in the economic stabilisation of Albania during this period was played without any doubt by remittances sent by emigrants. According to several different sources, remittances constitute the main financial aid to the Albanian economy in this period. Korovilas (1999) argues that, by the mid-1990s, an estimated $\$ 700 \mathrm{~m}$ per month was being sent back home or, in other words, one quarter of the country's GDP.

During this period of greater stability in the economy of the country, internal migration rates started to increase continuously. The main destinations were the capital and the coastal and central regions, while the north-east was losing its population. The rise of internal migration in this period was influenced also by remittances from emigrants. International migration started to finance internal migration: family members of emigrants finally had the financial means to move internally within the country, towards better economic and geographical conditions and opportunities.

King (2003) argues that international migration, in the Albanian context, is usually a first step that is followed by an internal migration of other family members and, further on, by the reunion of the entire family in the case of return migration.

\section{7: the collapse of pyramid schemes ${ }^{10}$ - new waves of exodus}

The lack of a developed banking system 'forced' many people, especially emigrants, to invest their money in so-called pyramid investment schemes. At their peak, their 
nominal value amounted to almost half the country's GDP. A large part of the population, about two-thirds, invested their money in these financial schemes (Jarvis, 2000). Given their very high rates of interest, pyramid schemes became an easy source of income, to the point that many people sold their houses and properties to invest the money. Remittances accounted for the main investments in pyramid schemes; emigrants were sending more and more money to invest in such 'easy earnings' schemes.

The pyramids collapsed in early 1997. This collapse was accompanied by anarchy, chaos and nearly a civil war throughout the country. The economic and political developments achieved up to that moment were damaged and Albania descended into total chaos. ${ }^{11}$

The dramatic situation during this period triggered a new wave of massive emigration mainly to Italy and Greece. Once more, thousands of Albanians were on the exodus, either by boat to Italy or over land to Greece.

\section{9: Kosovo crises - Albania from a country of emigration to a country of immi- gration}

After the collapse of the pyramid schemes, aside of its dramatic consequences for the country and its population, the economy rapidly recovered. GDP was growing remarkably: 12 per cent in 1998 (King, 2005).

Suddenly Albania, while still a fragile society which was trying to come to terms with its difficult past, found itself converted into a country of immigration. In 1999, the Kosovo crises produced more than 500000 refugees moving to Albania. There are close cultural and ethnic ties between both countries. They also share the same language. However, in the actual situation, this represented a major source of pressure on the economy of the country.

Furthermore, many of the Kosovan refugees used Albania as a transit point to migrate to other western countries. According to King (2005), many Albanians from the north mixed themselves with Kosovans in search of asylum in other countries.

2000-2007: towards a stable economic and political situation - controlled emigration and continued urbanisation

In the years following 2000, after the Kosovo crises were over, the economic conditions and political situation started to stabilise. Moreover, the data in existence suggest that international migration since 2000, and especially since 2002, has been steady and that no peak of mass migration has been observed.

Nevertheless, Albanian politics and the economy continue to be dominated by corruption, the mismanagement of public funds and poor economic planning in gen-

10 Pyramid schemes are informal financial institutions in which people invest their money while getting very high rates in return. Albania's formal financial system was rudimentary. After the transition, there were few private banks. With the banks unable to satisfy private sector demand for credit, an informal credit market grew, based on family ties and financed by remittances (Jarvis, 2002).

11 By March 1997, large parts of the country, especially the south, were no longer under government control. Weapons depots were thrown open and more than one million weapons came into the hands of the people. During this period, a new wave of uncontrolled emigration began. 
eral (Vullnetari, 2007). In this situation, there are continuous regional disparities related to better economic developments in some regions and profound poverty in others.

During this period, the central region, and mainly Tiranë, has continuously attracted more people. The urban population in this region has increased by 45 per cent since 1990 (King and Vullnetari, 2003). The growth of Tiranë has continued during these years with the same rhythm and it is estimated to have become the residence of more than one-third of the total population by 2007.

According to further estimates, internal migration is expected to continue to follow the same trends which means a massive urbanisation of some areas and the depopulation of others. Albania remains a predominantly rural country although there are assertions stating the opposite. It is true that Albanian internal migration patterns are dominated, and will continue to be dominated, by large rural-urban flows. This continuing trend will soon lead to an urban population larger in size than the rural population.

\section{Conclusions}

The seventeen years of transition which led Albania from a planned towards a free market economy have changed the face of the country enormously. Developments following the democratisation processes have certainly effected dynamic socio-economic and political transformations. As such, these transformations have played a considerable role in changing the landscape of Albanian demography. Demographic changes are expressed in a decrease in the total population, a slowing down of the natural rate of increase, a chaotic and massive increase of the population in cities, an increased concentration of the population in the central and western part of the country and an abandonment of the remote north-eastern parts. Migration, internal and international, constitutes the main factor in these social and demographic changes.

Breaking out of the political and economic isolation imposed by the communist regime has contributed to a great spatial mobility of the population. Following the demise of the communist regime, during a period of rapid change in the economic and political situation, Albania experienced one of the most spectacular migration waves in Europe.

The primary aim of this article was to understand and to describe the migration levels and trends embedded in the context of transition and triggered by political and economic transformation. Furthermore, we discussed the role of migration, internal and international, on social and demographic changes. Our results confirm that the mass migration following the transition period has been shaped by the political changes and economic developments while being a facilitator of social and demographic changes.

Firstly, the chronology of migration, with alternate massive and more stabilised migration trends, has followed the path of economic and political transformations and developments. As such, periods of political and economic unrest have been accompanied by large flows of people moving from the country; while during periods of economic growth and political tranquillity, migration trends tend to be relatively stable. Emigration is affected mainly by economic crises, high levels of poverty and unstable political situations whereas internal migration is more related to economic development and growth that drives migrants towards regions which are better off. 
Secondly, the migration chronology proposes that internal migration happened as a second step in time following a wave of emigration. This result suggests that international migration is seen as a way to fund internal movements through remittances sent back home, creating the financial opportunity for families to undertake internal migration. Furthermore, political stability and economic growth, especially in certain regions, shape the pattern and direction of internal migration.

We have also seen the significant impact of migration on social and demographic changes in Albania. Migration, with its trends, intensity and selective character, has played a central role in the demographic transformation of society. This impact has both positive and negative aspects. The decrease in the total population and the regional redistribution are the main changes directly affected by mass emigration and internal movements. Furthermore, remittances; the selectivity of migration in terms of age and sex structure and educational level; the abandonment of peripheral rural regions and the massive urbanisation of others; the socio-cultural transformation of society and regions, such as the abandonment of older generations; the increase in divorce rates; and continued cultural confrontation are some of the socio-demographic changes facilitated by massive migration.

Further research is needed to explore the significant dependent relationship between socio-economic and political transformation and the migration phenomenon. However, we believe that the current article provides some insights and enhances our understanding of the complex relationship between migration and the transformation processes that are still going on in Albania. In particular, this article suggests that, to control mass migration first, there is a need to have a stable political situation and more homogenous economic development in the country. Secondly, given the intensity and magnitude of migration flows, it is important to control its negative impact on socio-economic and demographic changes.

Migration during this period (internal as well as external) was chaotic and not regulated by any migration policy. Albania needs to adapt and implement effective migration policies in order to minimise the costs and maximize the benefits of migration. King et al (2003) has suggested that it is important to understand how to obtain positive effects from migration in such a way as to minimise costs and the risks. Migration can potentially be an advantage for countries going through a political and economic transition, as is Albania, where the situation is not stable and the future uncertain. To do so, there is a need to improve actual migration policy, implement new initiatives and create a collaboration between national and international policies.

An important role in a situation of over migration flows should be played by additional research, which can contribute towards a better understanding of these important social, economic and political phenomena in Albanian society. Additional studies may help in the implementation and promotion of effective policies and appropriate decisions to enhance the situation of migrants and their families, as well as to stabilise the socio-economic conditions of households and the country in general. 


\section{References}

Aliaj, B, K. Lulo and G. Myftiu (2003) Tirana: The Challenge of an Urban Development Tiranë: Cetis.

Banja, H (1990) 'Forcimi i metejshem i drejtimit me llogari me vehte i ndermarjes Socialiste' Probleme Ekonomike 37(8): 2, pp.27-46.

Barjaba, K (2000) 'Contemporary Patterns in Albanian Migration' South-East Europe Review for Labour and Social Affairs 3(2): 57-64.

Barjaba, K (2003) Shqiptarët Këta Ikës të Mëdhenj Tiranë: Korbi.

Bërxholi, A (2005) 'Veçoritë e vizualizimit të dinamikës së popullsisë në “Atlasin gjeografik të popullsisë së Shqipërisë”' Studime Gjeografike 15: 156-70.

Bërxholi, A, L. Hana, R. Lulo, E. Çaro, M. Xhaxhiu, L. Seferkolli, E. Zeqiri, A. Zotaj and A. Gjeçka (2005) Ristrukturimi Agrar Postkomunist në Shqipëri dhe Implikimet e Tregut të Punës Raport Vlerësues Studimor Tiranë: Akademia e Shkencave, Qendra e Studimeve Gjeografike.

Boyle, P, K. Halfacree and V. Robinson (1989) Exploring contemporary migration New York: Addison Wesley Longman Ltd.

Bonifazi, C and D. Sabatino (2003) 'Albanian migration to Italy: what official data and survey results can reveal' Journal of Ethnic and Migration Studies 29(6): 967-95.

Carletto, G, B. Davis, M. Stampini, S. Trento and A. Zezza (2004) Internal Mobility and International Migration ESA Working Paper 04-13, FAO: Rome.

Castaldo, A, J. Litchfield and B. Reilly (2005) 'Migration and poverty in Albania: what factors are associated with an individual's predisposition to migrate?' Journal of Southern Europe and the Balkans 7(2): 157-173.

Cole, J and I. Filatotchev (1992) 'Some Observations on Migration within and from the Former USSR in the 1990s' Post-Soviet Geography 33(7): 432-453.

Doka, Dh. (2005) 'Zhvillimet socio-ekonomike dhe rajonale te Shqipërisë pas vitit 1999’ Studime Gjeografike 24, Posdam.

Fuga, A, R. Gjoka and Z. Dervishi (1998) Between Cultural Remote, Desolation and Invigoration Tiranë.

Gardner, Robert W (1981) 'Macro level influences on the migration decision process' in Gordon F. De Jong and Robert W. Gardner (eds.) Migration decision making New York: Center for Cultural and Technical Interchange between East and West, Inc.

Gëdeshi, I, H. Mara, R. Dhimitri and K. Krisafi (1999) Emigrimi i Elitës Intelektuale nga Shqipëria Gjatë Periudhës së Tranzicionit (Migration of the Intellectual Elite During the Transition Period) Tiranë: Luarasi.

HDPC (2002) Albanian Human Development Report 2002 Human Development Promotion Centre, UNDP: Tiranë.

INSTAT (1989) Indicators by prefectures 1986-1989 Tiranë.

INSTAT (2001) Migration in Albania Population and Housing Census 2001. Tiranë: INSTAT. 
INSTAT (2002) Labour Force, Employment and Unemployment Tiranë: INSTAT.

INSTAT (2004) People and Work in Albania Tiranë: INSTAT.

IMF Economic Reviews (1994) Albania International Monetary Fund: Washington, D.C.

IMF Economic Reviews (2006) Albania International Monetary Fund: Washington, D.C.

Jan Kok, H (1999) Migration in Hungary and Poland before and after the transition $\mathrm{PhD}$ dissertation, Urban Research Centre: Faculty of Utrecht.

Jarvis, C (2000) 'The rise and fall of Albania's pyramid schemes' Finance and Development 37(1): 1-29.

Korovilas, J (1999) 'The Albanian economy in transition: the role of remittances and pyramid investment schemes' Post-Communist Economies 11(3): 399-415.

King, R (2003) 'Across the Sea and Over the Mountains: Documenting Albanian Migration' Scottish Geographical Journal 119(3): 283-309.

King, R and J. Vullnetari (2003) Migration and development in Albania Working Paper C5: Sussex Centre for Migration Studies, UK.

King, R (2004) 'Albania: interrelationships between population, poverty, development, internal and international migration Mediterranee 3(4): 37-47.

King, R (2005) 'Albania as a laboratory for the study of migration and development' Journal of Southern Europe and the Balkans 7(2): 133-155.

Kupisezewski, M, H. Durham and P. Rees (1996) Internal Migration and Regional Population Dynamics in Europe: Polish Case Study Working Paper 97/03, School of Geography: University of Leeds, UK.

European Training Foundation (2006) Labour Market Review of Albania.

Lami, Remzi (1999) Albania - 9 years after http://www.hartford-hwp.com/archives/ 62/index-ga.html [accessed on 12 October 2007].

Layard, R, O. Blanchard, R. Dornbusch and P. Krugman (1992) East-West Migration: The Alternatives Meet Press: Cambridge, MA.

Lee, S. E (1996) 'A Theory of Migration' in R. Cohen (ed.) Theories of Migration An Elgar Reference Collection: Cheltenham, UK; Brookfield, US.

Misja, V (1998) Emigracioni Ndërkombëtar në Shqipëri Gjatë Periudhës së Tranzicionit (Emigration in Albania During the Transition Period) Tiranë: Marin Barleti.

Muco, M (2001) 'Albania' Journal of South-East European and Black Sea Studies 1(1): 119-131.

Mullan, B (2001) Patterns of Migration and Economic Liberalization in the Balkans paper presented at the Centre of Refugee Migration Studies, Tiranë: Albania.

Nicholson, B (2002) 'The Wrong End of the Telescope: Economic Migrants, Immigration Policy, and how it looks from Albania' The Political Quarterly 73(4): 436-444. 
Pastore, F (1998) Conflicts and Migration: A Case Study of Albania written briefing addressed to the Conflict Prevention Network of the European Commission (revised version).

Sadiraj, Klartia (1999) Albania: Transition to a Market Economy Amsterdam: Tinbergen Institute Research Series, PhD dissertation.

Sjoberg, O (1992) 'Underurbanisation and Zero Urban Growth Hypothesis: Diverted Migration in Albania' Geografisika Annaler. Series B, Human Geography 74(1): 3-19.

Sjoberg, O and T. Tammaru (1999) 'Transitional Statistics: Internal Migration and Urban Growth in Post-Soviet Estonia' Europe-Asia Studies 51(5): 821-842.

UNDP-Albania (2000) Albanian Human Development Report 2000 Tiranë: UNDP Albania.

UNDP-Albania (2002) Albanian Human Development Report 2002 Tiranë: UNDP Albania.

Vullnetari, J (2007) Albanian Migration and Development: State of the Art Review IMISCOE Working Paper 18.

World Bank (2007) Albania Urban Sector Review.

World Bank and INSTAT (2003) Poverty During Growth WB Group: Washington DC. 